\title{
At Stake with River Basin Development in Eastern Africa
}

In the time of our fathers and grandfathers, our land was the land of good grass and it was big. The grass was tall for our cows and we moved our herds apart when danger came. The river gave us what we needed -water and grass for our animals. Our life was good. But look at our land now! It is bare and you can find our dying animals everywhere. Look at those carcasses! Our fathers and grandfathers did not know this hunger-they did not know this life. We have had to bring our villages to the river to find grass for our animals and to plant so we can feed our children. The poorest of us are even fishing. Now we are afraid that we will lose our river waters. What is happening to our river and our lands-do you know?

[Dasanech male elder in the western Omo River delta, within Ethiopia]

\begin{abstract}
River basin development in Africa has nearly unparalleled significance for the future of entire nations. Most major hydrodam projects undertaken in the continent have produced intense controversy, particularly over their socioeconomic and environmental impacts. In eastern Africa, river basin development is producing a major humanitarian and human rights crisis for a half million indigenous people in the border region of Ethiopia, Kenya and South Sudan. This crisis stems from developments in the Omo River basin of southwestern Ethiopia, with major international support. Construction of the Gibe III hydrodam - one of the world's tallest - is primarily geared to the production of hydroelectricity for the benefit of commercial and financial interests within Ethiopia and energy export throughout eastern Africa, as well as to major irrigated commercial agricultural development along the Omo River. The crisis at hand is an international one, especially since the Omo River is a transboundary watercourse-flowing from the Ethiopian highlands to its terminus within Kenya at that nation's Lake Turkana, where it provides most of the lake's water. The combined hydrodam and large-scale irrigation agriculture development would cause radical reduction of both river flow volume and lake level - thus destroying pastoral, agropastoral and fishing livelihoods of hundreds of thousands of indigenous people dependent on these waters. Catastrophic level collapse of survival systems in the region would usher in major new inter-ethnic, cross-border armed conflict as communities are forced to fight over the region's vanishing resources. Major human rights violations involving national governments and key international aid agencies are already underway.
\end{abstract}

\section{River Basin Development in Africa: Development Versus Disaster}

$>$ Few development initiatives in Sub-Saharan Africa have the economic and political importance of river basin developments, whether in terms of the sheer size of undertaking, magnitude of social and environmental transformation, impact on the future of entire nations or controversy regarding beneficial versus destructive outcomes. The range of people and institutions frequently engaging in heated controversy over these developments-from World Bank executives and Prime Ministers through multiple levels of technical specialists, water resource/engineering consultants and non-governmental or civil society organizations to villagers directly impacted—reflects the significance of such developments within African nations.

For African heads of state, the nearly unparalleled capital intensity of major dam and physical infrastructure projects, along with linked agricultural and industrial development, requires major infusions of international capital—nearly always 
as loans, viewed as a most powerful river impetus for economic growth and 'transformation' and inevitably termed "in the national interest." Assurances of major 'trickle down' of wealth and other benefits to the general population from such huge developments, moreover, are extended as promise of a 'better future'-while serving as a means of staving off increased or potential social unrest, as viewed by existing leaders.

International aid organizations, particularly multilateral development banks and major bilateral agencies, have for years held comparable enthusiasm for large dam and dam linked basin projects in Africa. The large size of loans extended for megadam development - well into the billions of dollars when dam-enabled projects are included, as well as the conditions attached to them-provide major donor countries and banks with opportunity for continued or expanded economic and political leverage in African nations along with major investment opportunities, access to natural resources and other benefits. Such developments are sometimes closely related to geostrategic objectives vital to donor country foreign policy.

Finally, rapid and definitive regional economic 'integration'—a major objective in foreign aid policies—can be rapidly advanced by dams generating hydroelectricity, along with major new infrastructure construction serving new industrialization, agro-industry and expansion of extractive industry interests.

Although most African river basins have been considered with reference to individual countries, a high proportion of them are actually transboundary in character-far more than the United Nations has officially recognized. In addition to major rivers that flow across national boundaries in eastern Africa, numerous others terminate at the Indian Ocean where their altered character has profound impacts on the biophysical, fisheries and other dimensions of coastal systems that extend across national boundaries.

$>$ A major boom in river basin development unfolded within Africa in the post World War II years-one primarily under the auspices of international aid programs as the region's nations became independent from their colonial administrations. This boom in development was dominated by the United States for years, since its economy and domestic experience at the end of the war fostered strong incentive as well as potential to move its dam-building approach and expertise to Africa, Asia and Latin America. This dominance in African basin development lasted until a number of European nations also took on major roles in dam-building in the 1970s.

The U.S. modeled its approach after its own Hoover dam and Grand Coulee dam (at the Nevada-Arizona border and in Washington state, respectively) and its Tennessee Valley Authority - a U.S. government owned entity created by the U.S. Congress in 1933 to oversee river basin development. ${ }^{1}$ A highly controversial and centralized planning effort introduced as part of President Franklin D. Roosevelt's New Deal, the TVA was broad spectrum in its roles which ranged among major dam construction, water and land policy coordination and management, and numerous other basin development initiatives, including agricultural ones.

These developments were part of a new centralized planning under President Roosevelt's New Deal that included elevating water resource policy to a key executive concern, with strong emphasis on 'harnessing' energy and promoting economic development. The rise of a new 'techno-managerial' approach to water resources and river basin development emerged as a major fulcrum of economic expansion in a market economy. This new wave had clearly already swept up some of the most prominent water resource economists, geographers and other scientists and technicians. ${ }^{2}$

$>$ The most ardent critics of major dam and basin developments have long pointed to their major social and environmental problems and injustices, including the human rights violations that have accompanied them. Denial of U.N. recognized human rights - including rights to water, health, livelihood, and freedom from forced relocation and political repression is widespread in river basin developments within Africa. In many ways, they parallel the many controversies occurring since the 1980s, in particular, between river basin developeers and their critics. However, these rights violations take an extreme form in the lowermost Omo River basin and northern Lake Turkana region, as detailed in the next chapters.

\footnotetext{
${ }^{1}$ Two comprehensive histories of international dam and river basin development are by Patrick McCully (2001) and Leslie (2005)—McCully taking a worldwide view and Leslie emphasizing cases in India, South Africa and Australia.

${ }^{2}$ Among the rising figures in this realm was Gilbert F. White, who was elevated to an executive water resource advisory position as a young man in his twenties by President Franklin D. Roosevelt. A biographical account of Gilbert White's life from the New Deal 1930s to the 2000s (Hinshaw 2006) provides an excellent view of the origins of these policies and their general application in international development. After playing a major role in megadam projects throughout much of Africa, Southeast Asia and the U.S., White became more equivocal (from the late 1980s onward) about the 'techno-managerial' approach in river basin/large dam development.
} 
Key components of the 'techno-managerial approach' to major river basin developments - are 'scientific' reports (mandated by international and national development agency operational principles) includes feasibility and baseline studies as well as impact assessments - all typically commissioned by the very governments, aid organizations and transnational companies participating in the intended development. These are generally produced by firms and individuals within the global consulting industry - a multi-billion dollar industry whose members are 'trusted' repeat contractors. Documents produced by the global consulting industry generally endorse the overall thrust of the intended developments, with limited consideration of social and environmental potential impacts and with 'suggestions' for risk-minimization, mitigation and monitoring measures. These are typically based on the assumptions that the projects will continue to completion and that any projected social or environmental impact problems can be "solved" by technical and managerial action. Such legitimation efforts generally lead to project approval in eastern African nations and may other development country contexts, whereas in developed countries, criticism and opposition by experienced constituencies frequently delays or even blocks such projects.

This clash of perspectives between large dam developers and critics has nowhere been clearer than in the proceedings of the World Commission on Dams (WCD), with its comprehensive report of 2000. By now, the results of the detailed WCD studies and deliberations have been extensively reported on and evaluated. The optional guidelines produced by compromises among Commission members are just that: optional. The rush to megadam development and major river basin industrialization has continued, however-in fact, recently intensified.

The World Bank has in 2013 stated its intention to rejuvenate, or increase its emphasis on large dams in developing countries, and both environmental and social 'safeguards' of the multilateral development banks - notably the World Bank as the lead institution, and the African Development Bank are actually in the process of being substantially weakened, not strengthened.

One of the strongest indictments of large dams has been produced by economists Ansar, Flyvbjerg and associates at the University of Oxford's Said School of Business - in a sense, using the dam developers' own criteria of 'success.' The study was based on an investigation of the real costs of 245 large hydrodams - all built between 1934 and 2007 in 65 countries on five continents. This study represents the "largest and most reliable data set of its kind" with portfolios "worth USD 353 billion in 2010 prices" (Ansar et al. 2014). Ethiopia's Gibe III dam was included in this study, as noted below.

Using measures including the gap "between managers' forecasts and actual outcomes related to construction costs, or the cost overrun, and implementation schedule, or schedule slippage," Ansar, Flyvbjerg and associates concluded the following:

"We find that even before accounting for negative impacts on human society and environment, the actual construction costs of large dams are too high to yield a positive return” (ibid.).

Ansar and colleagues specifically cite Ethiopia's [Gilgel] Gibe III dam, along with other large dams in planning stages stating that these are "likely to face large cost and schedule overruns, seriously undermining their economic viability." The matters of:

- Environmental and social impacts on local populations

- Risk of dam collapse, and

- Major debt incurred by African peoples

are noted as important additional considerations by the Oxford business group.

$>$ It is clear that something has gone terribly wrong in the realm of development policy formulation and implementation in terms of the gap between the rhetoric and the reality of macroeconomic and social/environmental outcomes. Megadams and linked river basin developments have frequently been documented to cause extensive livelihood destruction with widespread malnutrition, disease contraction, irreversible natural resource losses and increasing economic inequality, yet they persist as cornerstones of aid funded national development programs in Africa, including in the eastern region. 
In order to answer the question of how such a gap exists between the evidence for negative effects of large dam and basin developments, on the one hand, and the surge of megadam and linked river basin development, on the other, it is necessary to take full account of the political and economic origins, objectives and 'marketing' of policies within Africa and internationally.

This book will consider these issues for the transboundary region of Ethiopia-Kenya-South Sudan/llemi Triangle (a contested area), where the Omo River - a major river originating in southwestern Ethiopia—flows into Kenya's Lake Turkana (Fig. 1.1). The Ethiopian government's interests in the Omo basin center on the construction of the Gibe III megadam, an extensive system of dam-dependent irrigated agricultural enterprises and an electricity export transmission line from Ethiopia to Kenya - the first step in a multi-nation, eastern Africa energy 'highway' promoting industrialization economic expansion. The pages to follow trace this development, its origins and unfolding through the matrix of national and international policy-making, and its predictable impacts on hundreds of thousands of indigenous people in the Omo basin within Ethiopia and a segment of Kenya, within the broad expanse of lands around Kenya's Lake Turkana and within the Ilemi Triangle/South Sudan.

\section{The Transboundary Character of Emerging Crisis in Eastern Africa}

$>$ The Omo River is an international river that flows from its source waters in the western highlands of Ethiopia to its terminus at Kenya's Lake Turkana. Lake Turkana is Kenya's largest freshwater body and derives about $90 \%$ of its waters from the river. Prior to emptying into Lake Turkana, the Omo River meanders through a broad, semi-arid expanse of lowland plains. The Omo's annual flood delivers a major 'pulse' of freshwater, sediment and nutrients to the Lake Turkana — vital contributions to the physical and biological integrity of otherwise saline waters.

The transboundary character of the Omo River stems from recent expansion of the Omo's delta into Kenya's Lake Turkana — placing the river's terminus and much of the delta well within Kenya's national boundaries (Fig. 1.2). In less than a half century, the active Omo delta has grown from a 'birdfoot' profile to an area of over $500 \mathrm{~km}^{2}$ - a major biodiversity area of wetlands and a mosaic-like pattern of other vegetation types.

The lower Omo River basin and Lake Turkana region is one of Sub-Saharan Africa's most culturally diverse areas-home to at least thirteen distinct ethnic groups speaking languages of Cushitic, Eastern Nilotic, Omotic and Afroasiatic origin (Fig. 1.3).

Those indigenous groups nearest the tri-nation border area - the Dasanech, Nyangatom and northern Turkana-are primarily pastoral or agropastoral by tradition (Figs. 1.4 and 1.5) and have remained so for centuries, although with many adaptations. The harsh, semi-arid environment in which they reside has contributed to their complex and flexible survival strategies for coping with changing environmental and social conditions.

The Omo River and Lake Turkana are core components of the survival systems for much of the region's indigenous groups, most of whose livelihood systems are transboundary in nature. The survival of more than 500,000 of the region's pastoralists, agropastoralists and fishers requires access to adequate water and living resources from the Omo River or Lake Turkana.

The region's ethnic groups most heavily dependent on the Omo River or Lake Turkana are the Mursi, Bodi, Kwegu, Suri, Kara, Nyangatom, and Dasanech, in the lower Omo River basin, and the Turkana, El Molo, Rendille, Samburu, Gabbra (and some Dasanech) along the shores of Lake Turkana (Fig. 1.3). ${ }^{3}$

Transboundary ethnic groups are linked together by a network of interethnic material and social exchange relations - a system essential to the survival of each individual group (Fig. 1.6). In recent years, however, nearly all transboundary groups have had to cope with a sharp decline in their capacity to sustain a pastoral life. This stress has reverberated to all groups - friends and enemies alike. The precipitous decline of the herding economy and pastoral life - virtual collapse in some areas - is largely the product of dispossession of resident groups at the hands of powerful external economic and political forces. Although they have sustained complex and flexible strategies for coping with periods of prolonged drought,

\footnotetext{
${ }^{3}$ Considerable literature has generated over the past half century regarding the environment and ethnic groups in the lower Omo basin, northern Turkana region and the borderlands of the Ilemi Triangle. Numerous selections are noted in later chapters.
} 


\section{Location Map of Proposed Gibe III Dam and Impact Area}

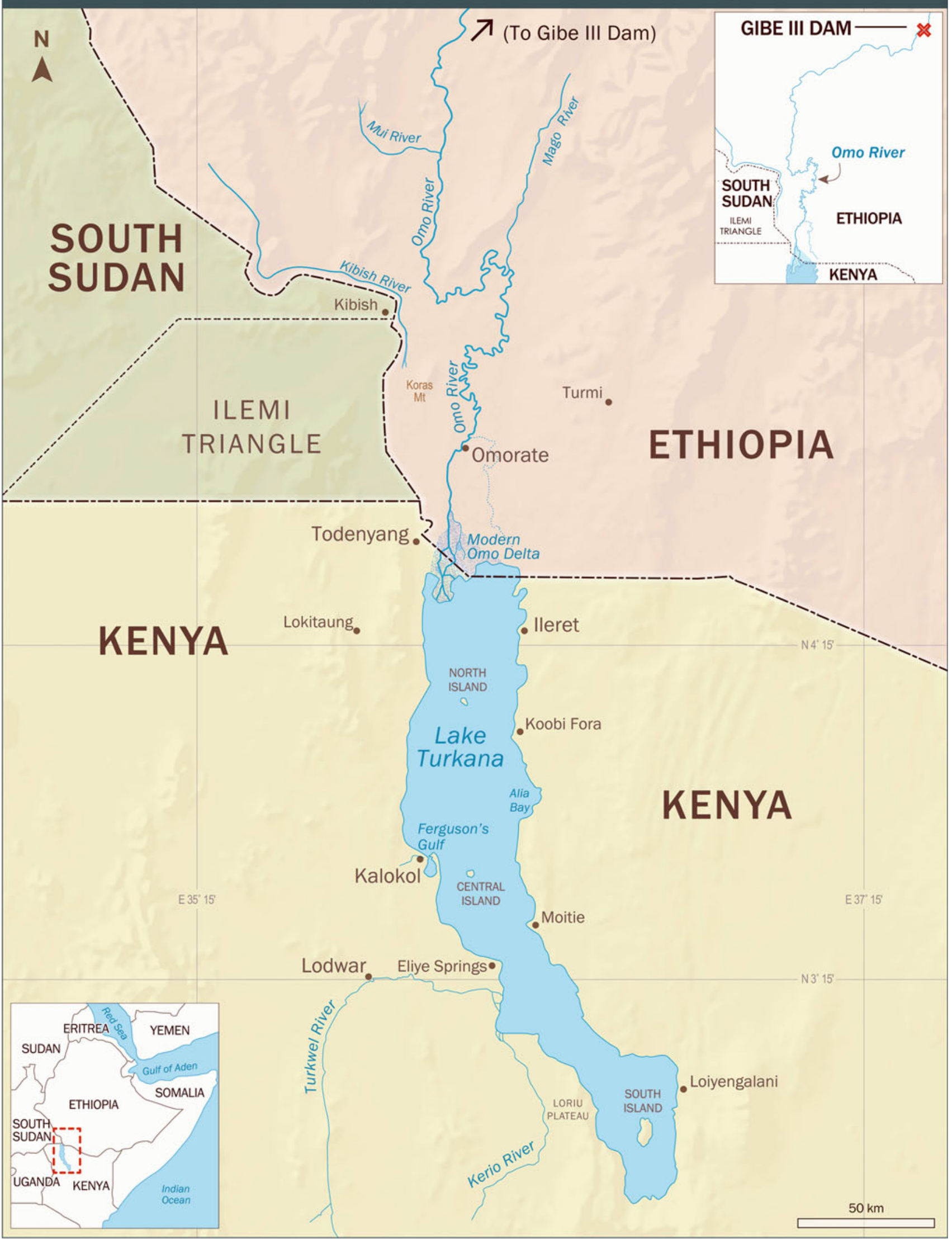

Fig. 1.1 Location of the Gibe III dam on the Omo River in the tri-nation transboundary region 


\section{Omo Delta Expansion; 1973 to 2005}

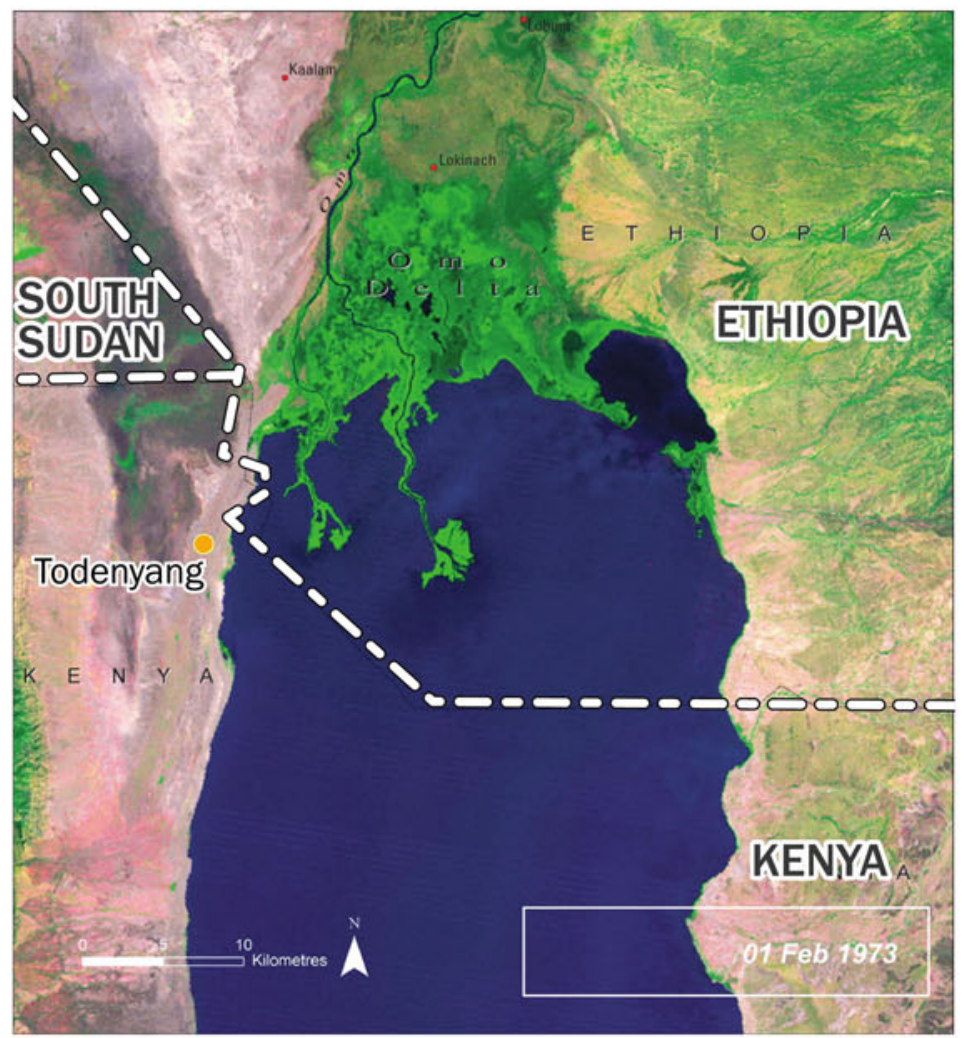

\section{3}
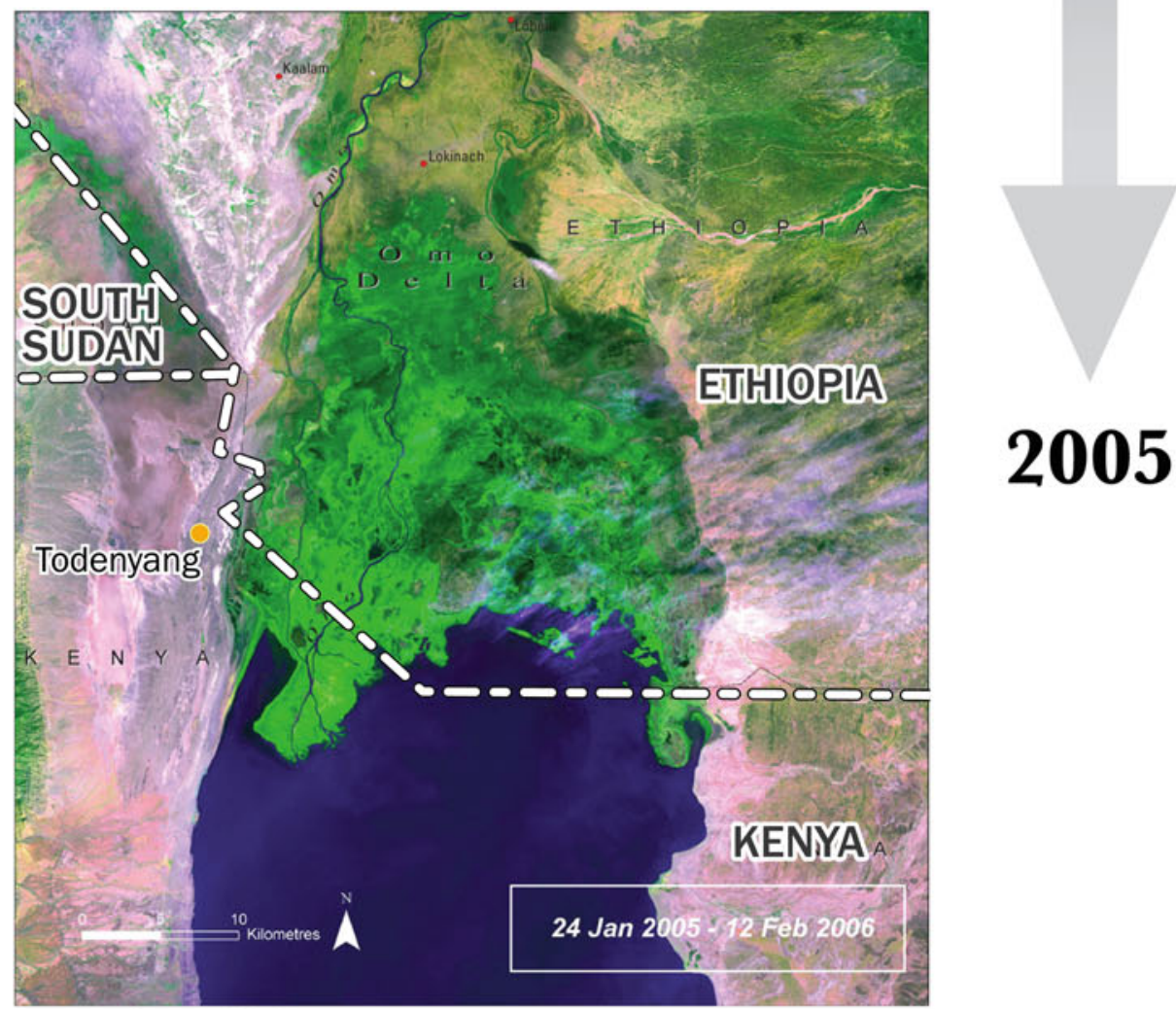

Imagery Source: NASA

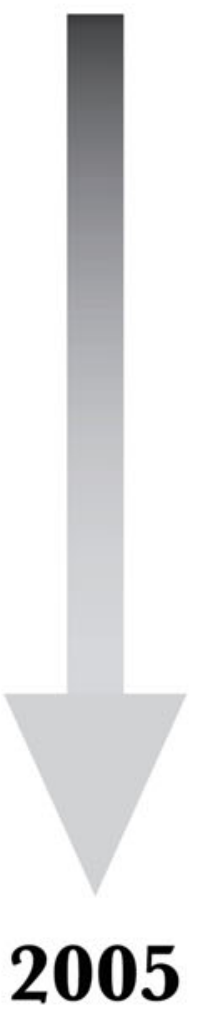

Fig. 1.2 Omo River delta expansion from 1973 to 2006 with the river's terminus in Kenya. Source original images from National Aeronautics and Space Administration (NASA). National borders and contested Ilemi Triangle section are added 


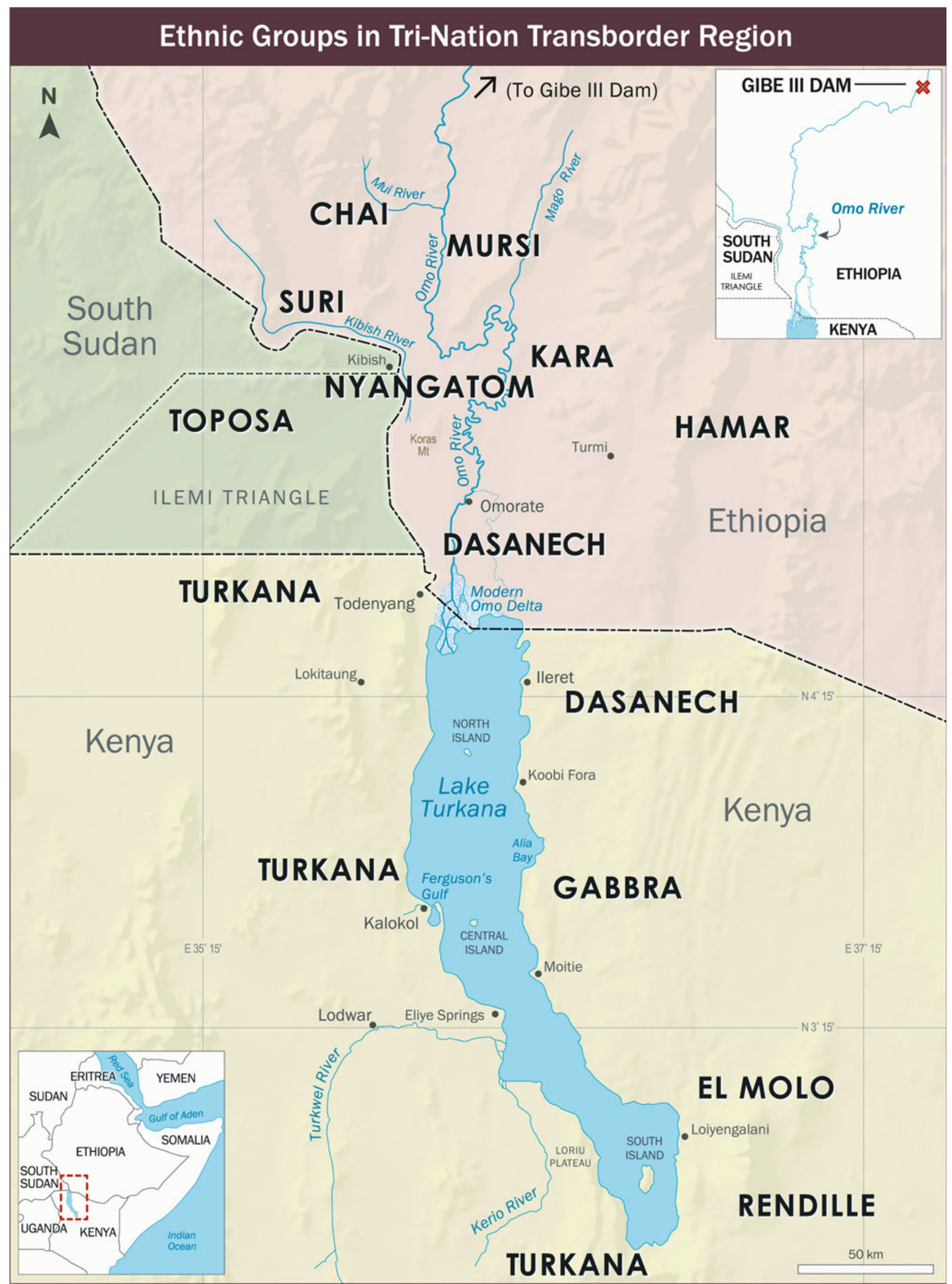

Fig. 1.3 Ethnic groups in the tri-nation transboundary region 

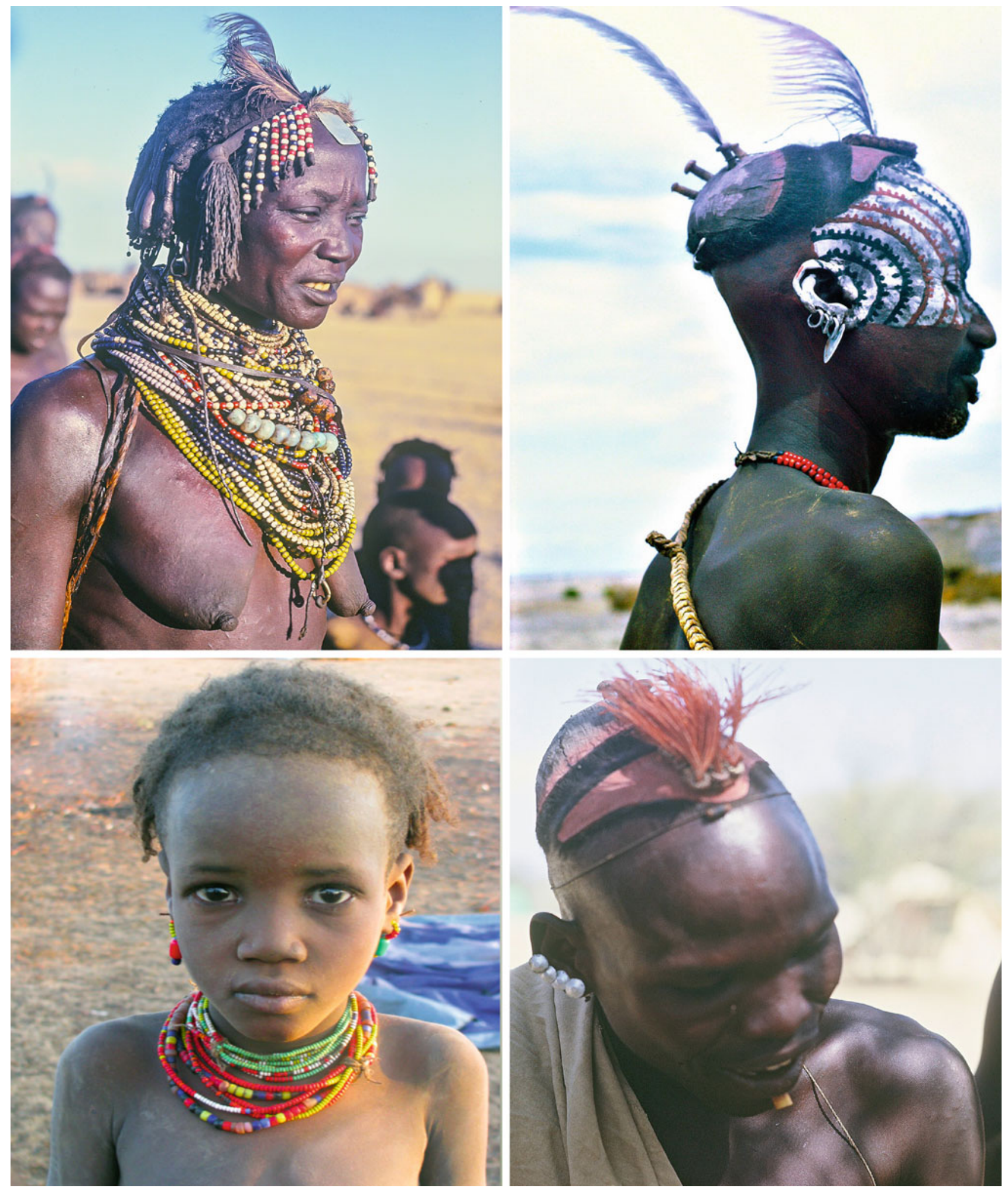

Fig. 1.4 Indigenous Dasanech and Nyangatom residents in the lowermost Omo River basin. Top left Dasanech elder woman (pastoral village). Top right Dasanech man at major ritual (dimi). Bottom left Young Dasanech girl. Bottom right Nyangatom man (agropastoral village at Omo River) 

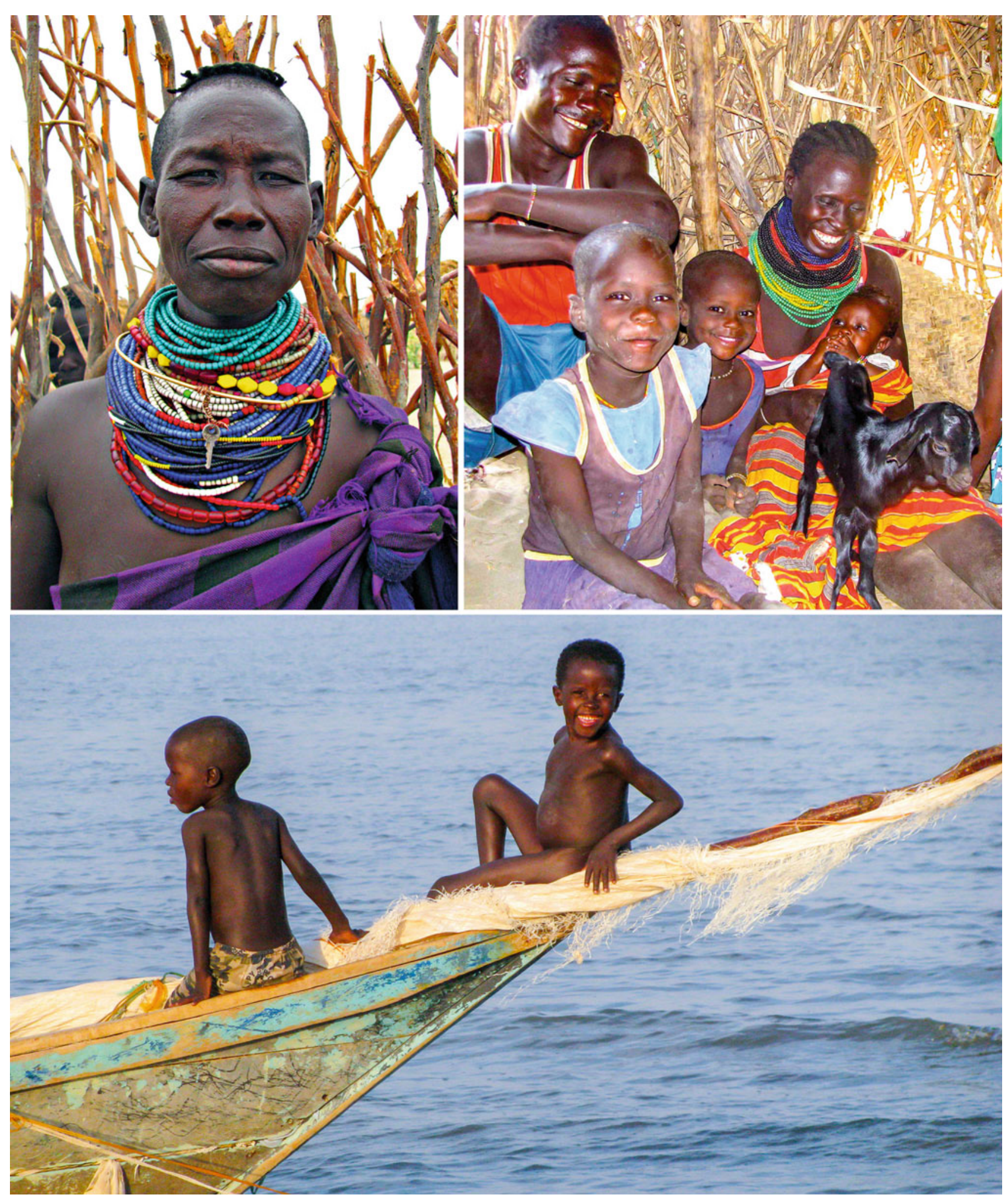

Fig. 1.5 Turkana villagers at Lake Turkana. Top left elder woman along northwestern shoreline. Top right fishing family near Kenya-Ethiopia border. Bottom Young boys on non-motorized sailboat 


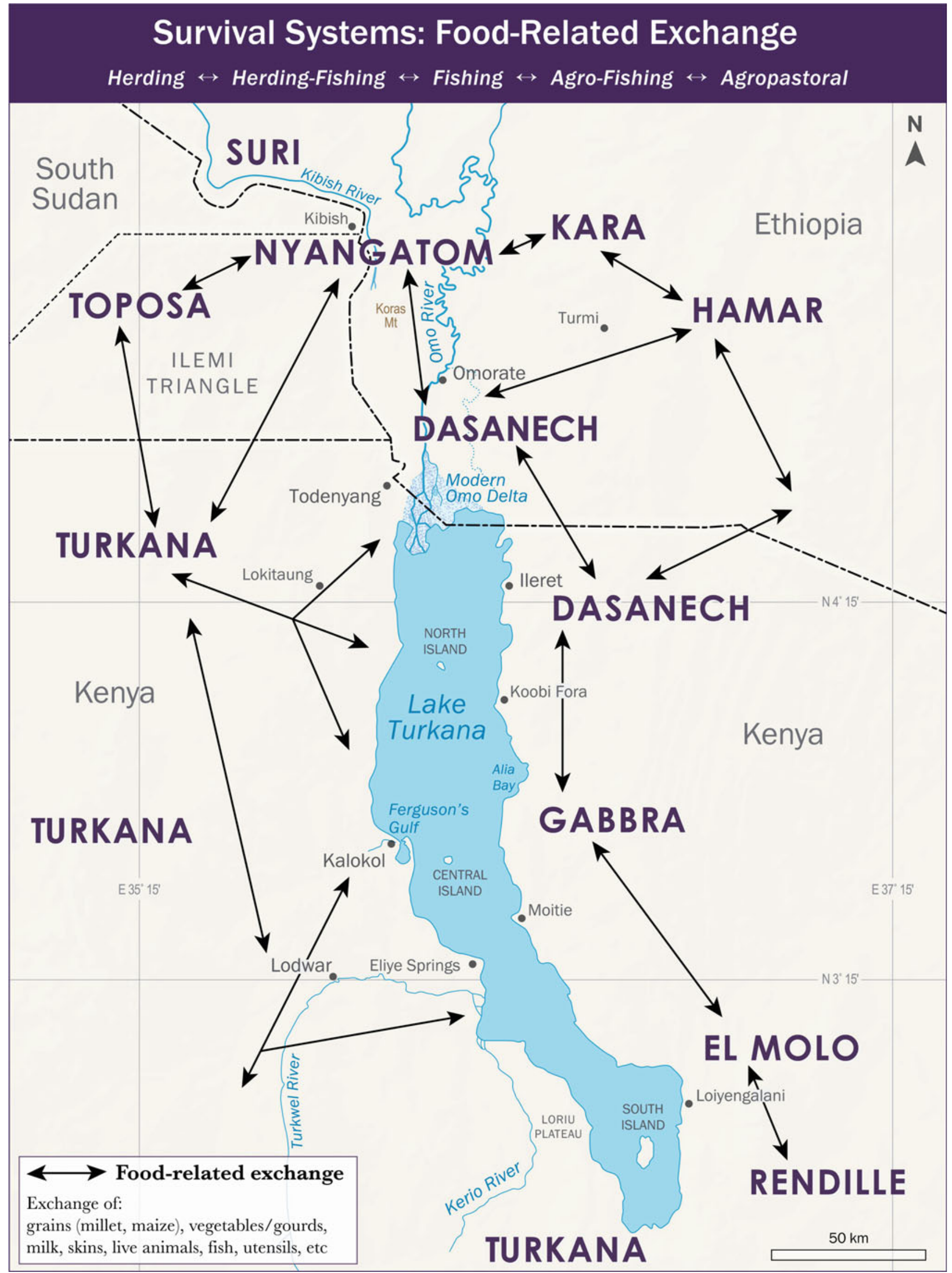

Fig. 1.6 Interethnic exchange network in the transboundary region 
disease epidemics social conflict and other hardships for centuries, the region's ethnic groups no longer have the conditions necessary for recovery from these major stress periods. For individual groups, these conditions center on access to sufficient land, pasturage and water resources in order to implement long-term livestock herd diversification, overall production diversification, and maintenance of strong internal reciprocity relations, among others.

Whole segments of these indigenous groups have been forced to migrate to lands along the Omo River and around the shores of Lake Turkana in recent years. Tens of thousands of Dasanech and Nyangatom residents have settled along the Omo River, where they rely primarily on different combinations of flood recession agriculture, livestock raising, fishing, wild food gathering and hunting. Thousands of other Dasanech have migrated from their Ethiopian lands to join Dasanech settlements along the extreme the northeastern shores of Kenya's Lake Turkana (Fig. 1.3), so the group is clearly cross-border in extent. In Kenya, hundreds of thousands of central and northern Turkana have coped with herd losses by moving toward Lake Turkana where they take up fishing, fishing/herding and a variety of secondary activities.

For many of the poorest pastoral and agropastoral households, livelihood activities that once served as temporary measures - for example, as a means of recovery after major livestock or crop losses or as secondary production — have become their principal means of survival. ${ }^{4}$ These activities include fishing, wild food gathering, chicken raising and household commodity production. Livelihood activities of the Dasanech Nyangatom and Turkana ethnic groups include those in Figs. 1.7 and 1.8. To a large extent, these production activities reflect major environmental variations created by the punctuation of the arid region by the Omo River, Lake Turkana, ephemeral streams, volcanic rock and tuffaceous outcrops, ancient beach ridges and floodplains, salt springs and other anomalous features (Fig. 1.9). ${ }^{5}$

$>$ The transboundary region was long an area of little concern to policy-makers in Ethiopia, Kenya and distant capitals, other than for determining national boundaries and securing borders. Recently, it has recently become the focus of major hydropower development, dam enabled irrigated commercial agriculture and oil/gas exploration. These developments either necessitate regulation of the Omo River or at least benefit from it in terms of infrastructure building and securing the region in political and military terms.

Oil and gas concessions are active throughout much of the transboundary region. Ethiopian and Kenyan governments frequently announce 'new' oil and gas discoveries through their national media. In reality, exploration began decades ago as part of a broad cooperation program among government, corporate and aid sectors. Systematic exploration has been underway for a half century in the eastern portion of Africa, from the Red Sea to southern Africa. Exploration activity in the transboundary region has recently escalated, both in geographic extent and activity level. Oil company work parties in the region are highly visible to indigenous communities, with some local groups vigorously opposing their incursion-for example, in Turkana lands. ${ }^{6}$ Appendix A of this book, written by J. Dimon with this writer's assistance, is a brief description of oil industry exploration in the transboundary region.

\section{The Gibe III Dam and Linked Agricultural and Power Export Developments}

$>$ The Gibe III dam represents a milestone project in Ethiopia's energy development. It was planned as the nation's first megadam - both to double the nation's power generation for domestic development (mostly urban and industrial) and to launch the export of Ethiopian hydrodam generated electricity to surrounding countries for a planned East Africa energy network supported by international aid. The Gibe III dam is part of a planned "cascade" of hydro projects along the Omo (Fig. 1.10). The relatively small Gibe I dam was completed and is operating, while the associated Gibe II power generating project has been under extensive repair following two tunnel collapse disasters. The Ethiopian government and international planners are planning two additional dams - the Gibe IV and Gibe V.

\footnotetext{
${ }^{4}$ Hunting was one of these opportunistic or temporary means of food-getting. Recent depletion of wildlife in both the lower Omo basin and the Lake Turkana region, particularly with the pervasive use of firearms, has eliminated this option, for all practical purposes.

${ }^{5}$ See the geological, geochemical and geomorphological studies by Brown et al. (2006), Bruhn et al. (2011), Cerling (1986) and Butzer (1970, 1971).

${ }^{6}$ For the most part, only a small number of local residents - mostly young men who have traveled among South Sudanese military groups and later returned to their home areas - are familiar with oil development within South Sudan, including its effects on local communities and as a cause of conflict.
} 

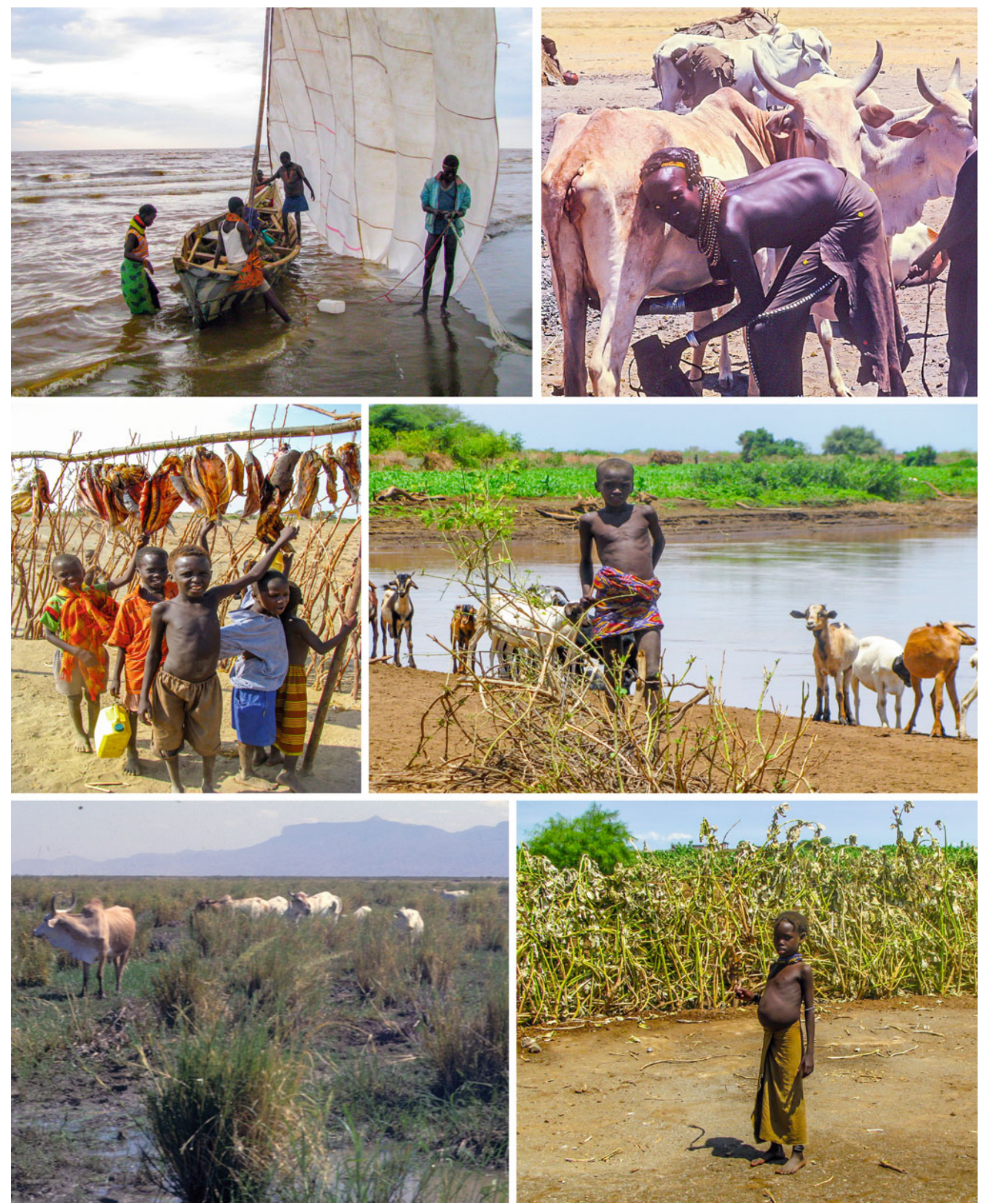

Fig. 1.7 Major livelihoods in the transboundary region. Top left Turkana fishing boat departing for expedition. Top right Dasanech pastoral village milking time. Center left Drying fish catch in a lakeside Turkana village. Center right Young Dasanech boy herding goats at Omo River with flood recession agriculture on nearby riverside flat. Bottom left Cattle grazing in annually flooded Omo delta wetlands. Bottom right Dasanech girl in flood recession farm plot 


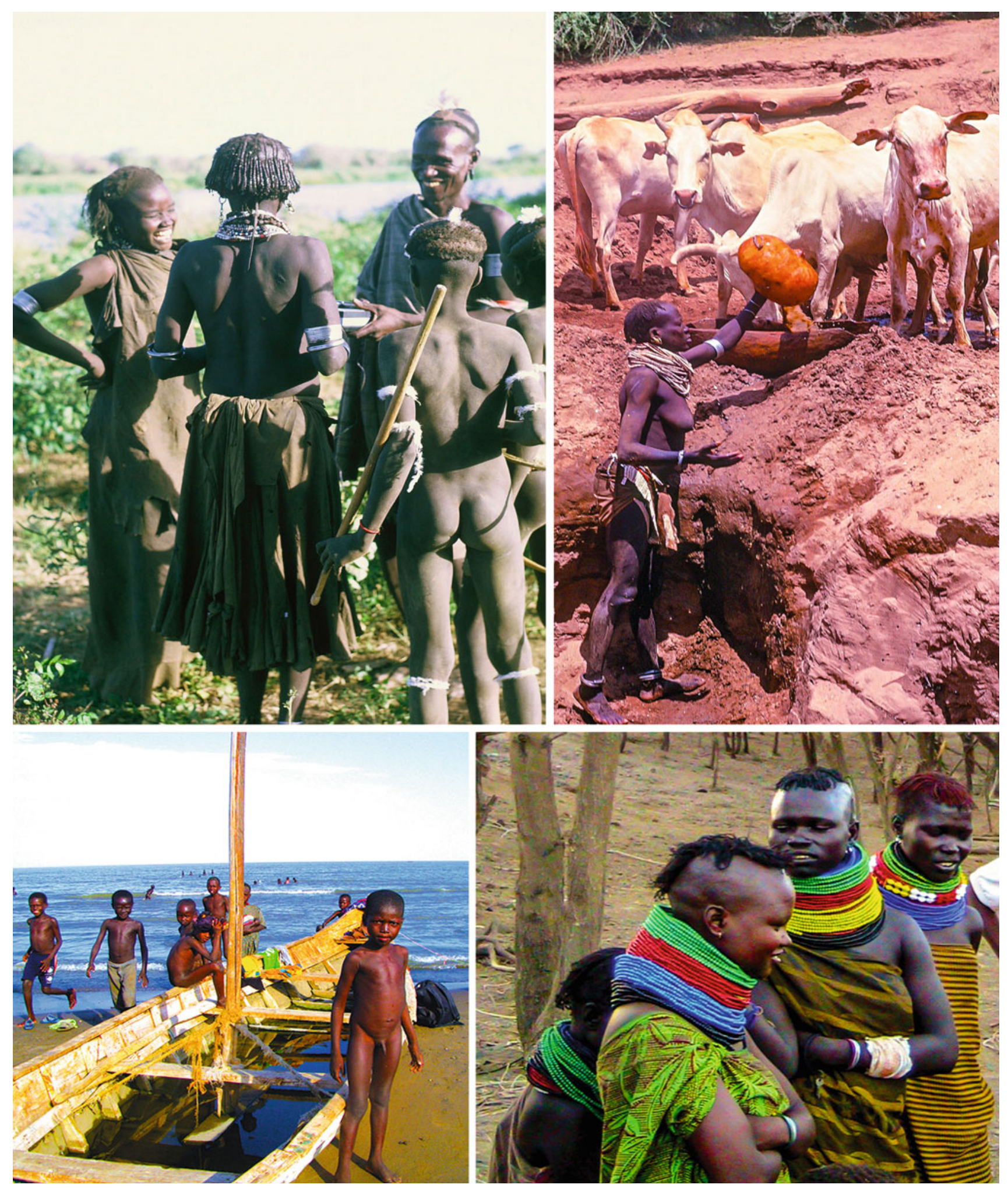

Fig. 1.8 Peoples of the tri-nation border region. Top left Dasanech agropastoral family at the Omo River. Bottom left Turkana children near fishing village at Lake Turkana. Top right Nyangatom woman at hand-dug well along seasonal Kibish River. Bottom right Turkana pastoral women in upland plains 

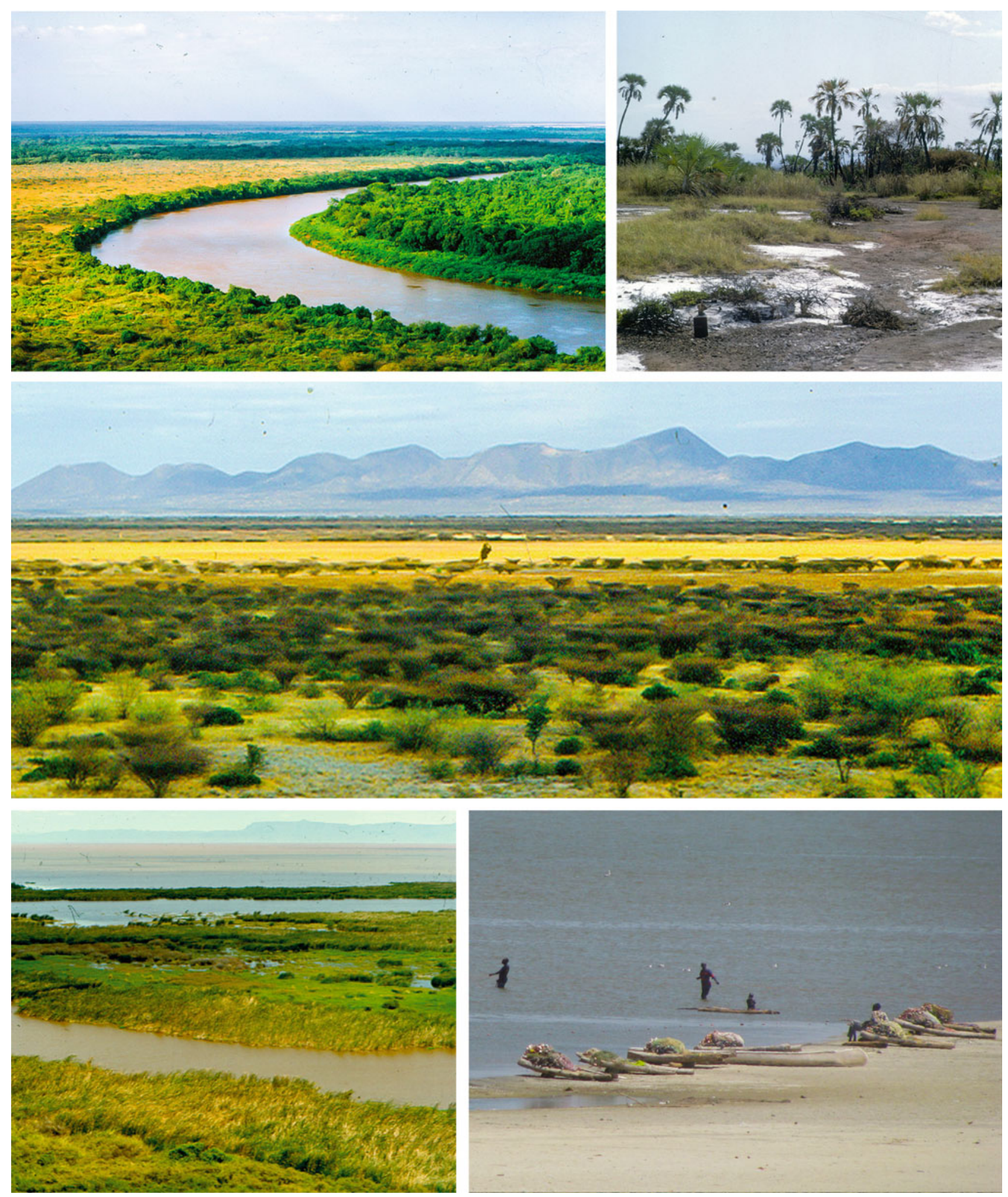

Fig. 1.9 Habitat variation in the transboundary region. Top left Meandering Omo River section in the lowermost Omo basin with forest and recession agriculture on the river's inside bend. Top right Salt springs with doum palms along the river. Center Upland plains with complex vegetation/soil patterns and volcanic highlands. Lower left Modern delta at the Omo River's inflow to Lake Turkana. Lower right Lake Turkana with extremely shallow western shoreline 


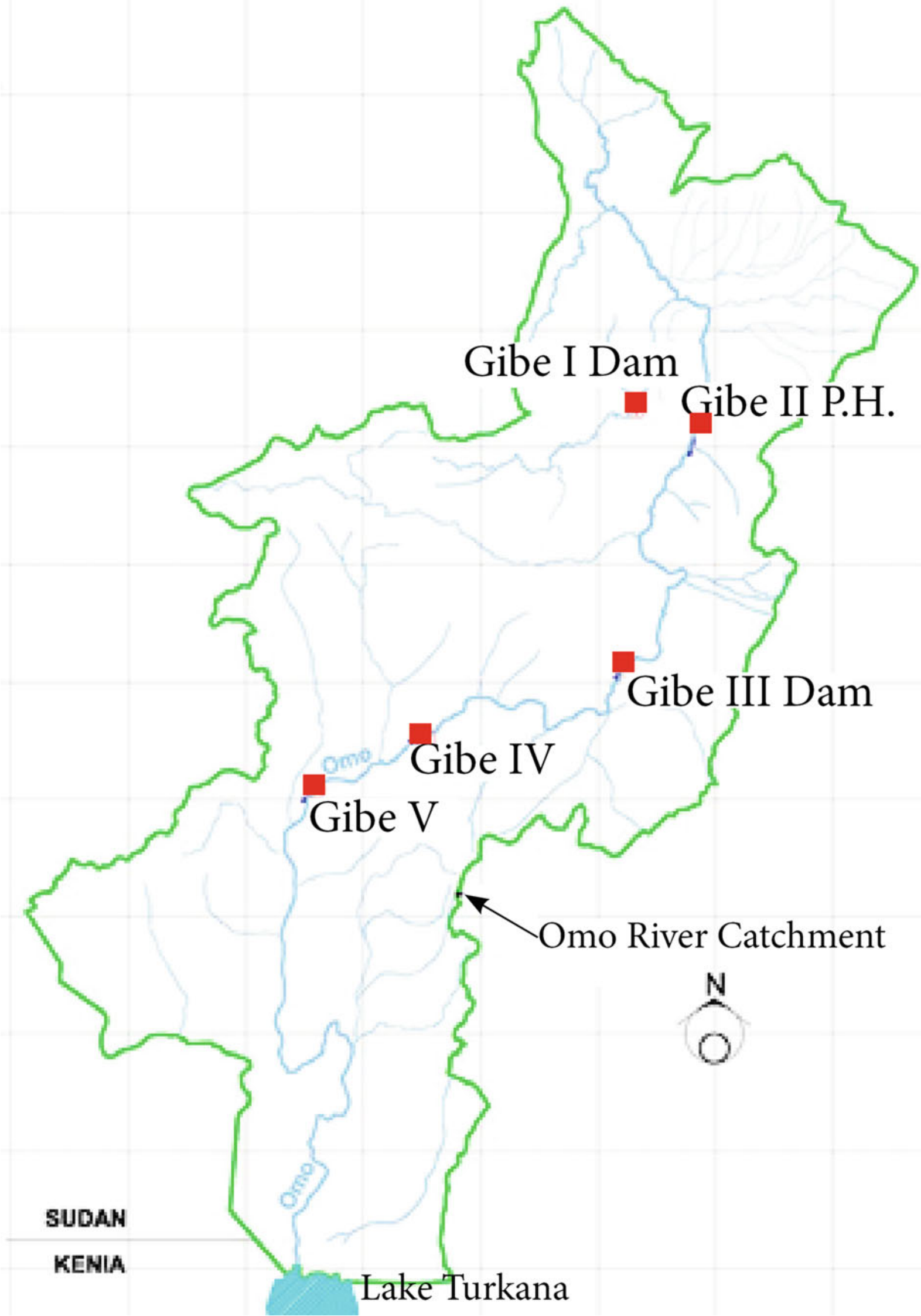

Fig. 1.10 The 'Gibe cascade' of hydrodam and electricity projects along the Omo River. Source GOE (2009a) 
At $243 \mathrm{~m}$ height - when completed, the Gibe III would rank as one of the tallest dams in the world. It is located in a deep gorge of the Omo River in Ethiopia's highlands, $464 \mathrm{~km}$ southwest of Addis Ababa (Fig. 1.11), with the coordinates $6.8472^{\circ} \mathrm{N} \times 37.3014^{\circ} \mathrm{E}$. Until the $6000 \mathrm{MW}$ Grand Ethiopian Renaissance Dam (GERD) on the Blue Nile is completed, the Gibe III would be Africa's largest dam. Initially designed as a rock-filled structure, this ill-advised Gibe III plan was later replaced by its present roller-compacted concrete (RCC) gravity design. ${ }^{7}$ The dam's reservoir is $150 \mathrm{~km}$ long, with an area of $210 \mathrm{~km}^{2}$ and a storage capacity of $14,700 \mathrm{~cm}^{3}$ - a volume equal to about two years of the Omo River's flow at the dam site. (According to GOE data, even the reservoir's live storage of 11,750 million cubic meters is greater than the second largest lake in Ethiopia-Lake Abaya). ${ }^{8}$

The dam is designed to generate 1870 Megawatts (MW) of electricity (6500 GWh per year) from ten turbines, each with 187 MW capacity. From the beginning, the Gibe III dam was planned for power production geared to both the domestic Ethiopian market and export markets in the eastern Africa region (see Chap. 2) - primarily by direct transmission to Kenya. By 2005, this export plan was explicitly viewed as key to the formation of the Eastern Africa Power Pool (EAPP) - a system designed to link the electricity grids of East African countries. A 2006 Inter-Governmental Memorandum of Understanding (MOU) formalized this export agreement when it was signed by the ministers of energy of both Kenya and Ethiopia (KETRACO 2006). ${ }^{9}$ The international development banks have played the key role in these arrangements, including through the signing of the MOU.

The official cost of the Gibe III dam is variously stated as EUR 1.47 billion to EUR 1.7 billion, with subsequent unofficial estimates of well above EUR 2 billion. A Chinese loan of USD 500 million accounts for a substantial portion of this cost, with government and investor funding making up the difference, after international development banks backed away from funding due to violations of their required procedures for project support (see Chaps. 2 and 10, where 'fungible' funding to the Ethiopian government from the international development banks is described). The dam's stated cost excludes those of major infrastructural construction costs for the dam and dam enabled agricultural and other development, as well as the cost of loans to the GOE for domestic and international power transmission systems. This cost also excludes the inestimably huge costs of disastrous human and resource consequences of the project as well as the GOE's alleged mitigation and management plans.

Although the Gibe III dam is clearly regarded by the Ethiopian government as primarily for power production, it is also publically described as 'essential' for the elimination of 'excessive floods' that are "destructive of human life and property"-statements dealt with in Chap. 6.

The World Bank, African Development Bank (AFDB) and European Investment Bank (EIB) have been major contributors to the Omo River basin's commercial development planning, feasibility, and early dam construction. Their internal operational policies for funding projects have by all reports prevented them from funding the Gibe III dam directly, however, because of the GOE's no-bid contracting, its failure to establish impact assessments prior to project inception and other violations of procedural requirements. The Chinese are widely viewed to have rescued the project, however, with their major loan approval.

Other development bank support for the Gibe III and Omo basin development include:

- Funding, coordination and encouragement of support for Ethiopia's bureaucratic apparatus spearheading this development.

- Funding for the GOE's establishment and maintenance of the political and economic context for dam and irrigated agricultural development - commonly dubbed 'basic services' provision, and most prominently.

- Funding for the major power transmission line from Ethiopia to Kenya for an East African 'energy highway' program-a system widely known to be planned for the inclusion of Gibe III generated electricity despite an approximately 50-km 'gap' between the transmission line and the dam for which Chinese funding was secured.

\footnotetext{
${ }^{7}$ A consultant to the African Development Bank issued the first major criticism of the rock-filled structure (Mitchell 2009) and a subsequent assessment by a European Investment Bank consultant raised similar criticism (EIB 2010). Insurance coverage for the rock-filled version was not forthcoming - likely a factor in Gibe III planners' shift to RCC construction (Hathaway 2008).

${ }^{8}$ Lake Abaya is recorded as having a live storage of 8200 million cubic meters.

${ }^{9}$ The other signatories were of Burundi, DRC, Egypt, Rwanda, and Sudan.
} 


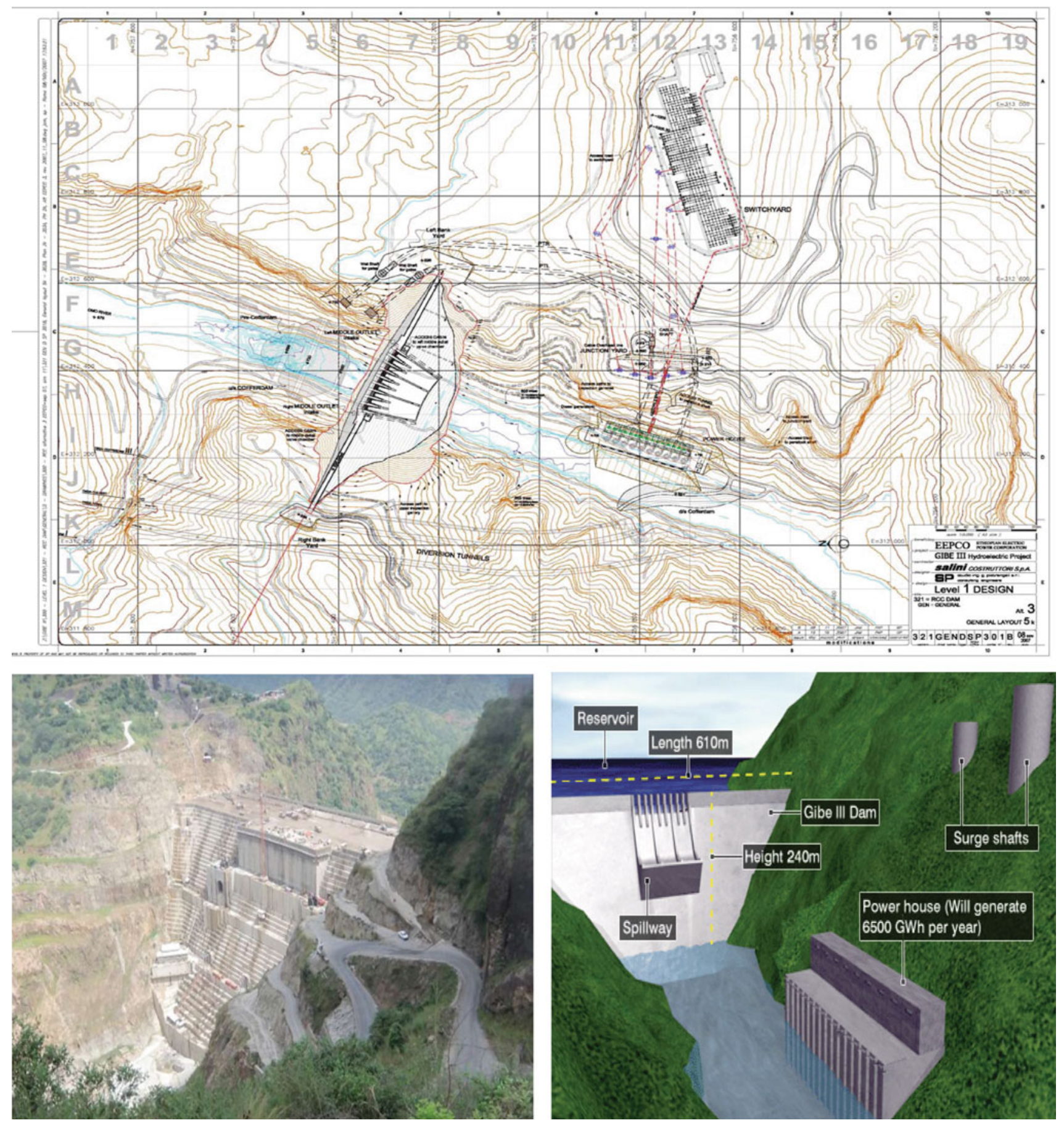

Fig. 1.11 Gibe III dam site and construction. Top Contour map indicating steep slopes/topographic features at the Gibe III dam site and components of the project complex (GOE 2009a). Bottom left dam in progress, with access road. Bottom right Idealized version of Gibe III plan. Source www.gibe3.gov.et

Longstanding plans for export of Gibe III generated electricity contributed to signing of a power purchase agreement whereby Kenya will buy approximately $400 \mathrm{MW}$ of electricity from Ethiopia for a period of twenty years (beginning in 2017). ${ }^{10}$ The plan for export of Ethiopian power, the details of which are outlined below, is part of the multi-billion dollar

\footnotetext{
${ }^{10}$ Among many reports of this agreement is that by Kenya Power and Lighting Co., Ltd. in its Kenya (2011/2012) Annual Report and Financial Statements.
} 
East Africa Power Pool (EAPP), spearheaded and largely funded by the World Bank and African Development Bank (AFDB). GOE officials and numerous aid officials have described the Gibe III dam as "the first step" in this program. ${ }^{11}$

The World Bank and the African Development Bank (AFDB) have both disclaimed any connection between the Gibe III dam and the major transmission line for power export from Ethiopia to Kenya that they are funding. These assertions are in line with the banks' internal regulations precluding their funding of the dam. This claim is not supported by the reality of the development, however, since the effects of these developments are cumulative and synergistic - a matter detailed in Chaps. 6 and 10. The same situation exists with regard to the AFDB's claim of "no relation" to the irrigated agricultural development along the Omo River, since the Gibe III and major dam enabled agricultural enterprises also have cumulative and synergistic effects.

$>$ The Gibe III dam and the irrigated agricultural enterprises it enables would usher in massive scale indigenous livelihood and natural resource destruction in the lowermost Omo basin, Kenya's Lake Turkana region and overall in the tri-nation border region. The dam would radically reduce the Omo River's downstream flow volume by at least 60-70\% and cause a precipitous decrease in inflow to Lake Turkana during the reservoir-filling period and beyond. ${ }^{12}$ Such loss of river flow volume would destroy critical fish reproductive and life cycle conditions and desiccate riverine and Omo delta habitats for flood recession agriculture, livestock watering and 'last resort' grazing. It would also eliminate the pristine Omo riverine forest, which is the last of its type in Sub-Saharan Africa and one of the richest remaining wildlife areas of Ethiopia. Figure 1.12 indicates the rich forest development bordering the Omo River in the semi-arid lowland portion of the river - as well as lowlying locales for recession agriculture along annually flooded riverside sand spits and waterside flats. These environments are vital to the survival of indigenous residents - pastoralists, agropastoralists and fishers. This destruction would be greatly worsened by dam enabled large-scale irrigated agricultural enterprises planned along the Omo River, many of which are already under construction.

The radical decrease in Omo River inflow to Lake Turkana would cause major lake likely retreat-most prominently in the shallow northern and central portions of the lake. The northern shoreline of the lake would recede by around $8-10 \mathrm{~km}$, for example, with multi-kilometer retreat of lake waters throughout much of the lake (see figures in Chaps. 4 and 5). Such retreat would cause the desiccation of near shore fish reproductive habitat leading to destruction of fish stocks that are essential to the survival of hundreds of thousands of fishing and pastoral/fishing indigenous residents, as well as destroy access to adequate and potable water by that population and the region's watering and lakeside grazing resources for untold the region's livestock.

Catastrophic level human destruction would have already occurred by even the end of the dam's closure for reservoir filling—itself a multi-year process. The GOE's 'artificial flood' program—espoused as a 'solution' after the filling period - would be entirely inadequate to prevent massive human destruction among Ethiopian and Kenyan communities residing below the dam. As detailed in Chap. 6, such programs are frequently 'promised' but never implemented in large dam development within Africa. The Ethiopian government itself has noted the real 'possibility' of no such artificial flood program or one of limited duration. Even the increased flood level suggested by a development bank consultant (EIB 2010) would be entirely inadequate for the bare survival of the region's resident population and the obstruction of remaining river waters by irrigated agricultural plantations would only worsen the crisis.

The destruction of pastoral, agropastoral and fishing livelihoods would swiftly produce a major humanitarian disaster, with widespread conditions of starvation, disease and spiraling interethnic armed conflict in the tri-nation border region as groups desperately compete for vanishing resources. Policies to effect the Gibe III dam and its attendant irrigation agriculture violate the U.N.-recognized human right to adequate water and its associated right to livelihood for hundreds of thousands of indigenous residents.

\footnotetext{
${ }^{11}$ Impact assessments and related studies, produced by global consulting firms and individuals through their contracts with governments and aid agencies (GOE, GOK, World Bank, AFDB, EIB, etc.) are referenced in this book to the contracting government or agency, not the global industry consultants. Exceptions to this are documents with multiple contracting agencies or non-agency documents produced by GCI firms or individuals.

${ }^{12}$ This period is dubiously defined by the GOE (2009b) as requiring one to three years - a length of time highly unlikely to be sufficient, according to Africa Resources Working Group (ARWG) physical scientists working in the area. This is due to the fractured nature of the reservoir's rock walls providing for major leakage from the reservoir. This matter is outlined in Chap. 3. No data has been recorded by the GOE for downstream Omo River flow volume or lake inflow prior to initiation of Gibe III dam construction, or in ensuing years.
} 

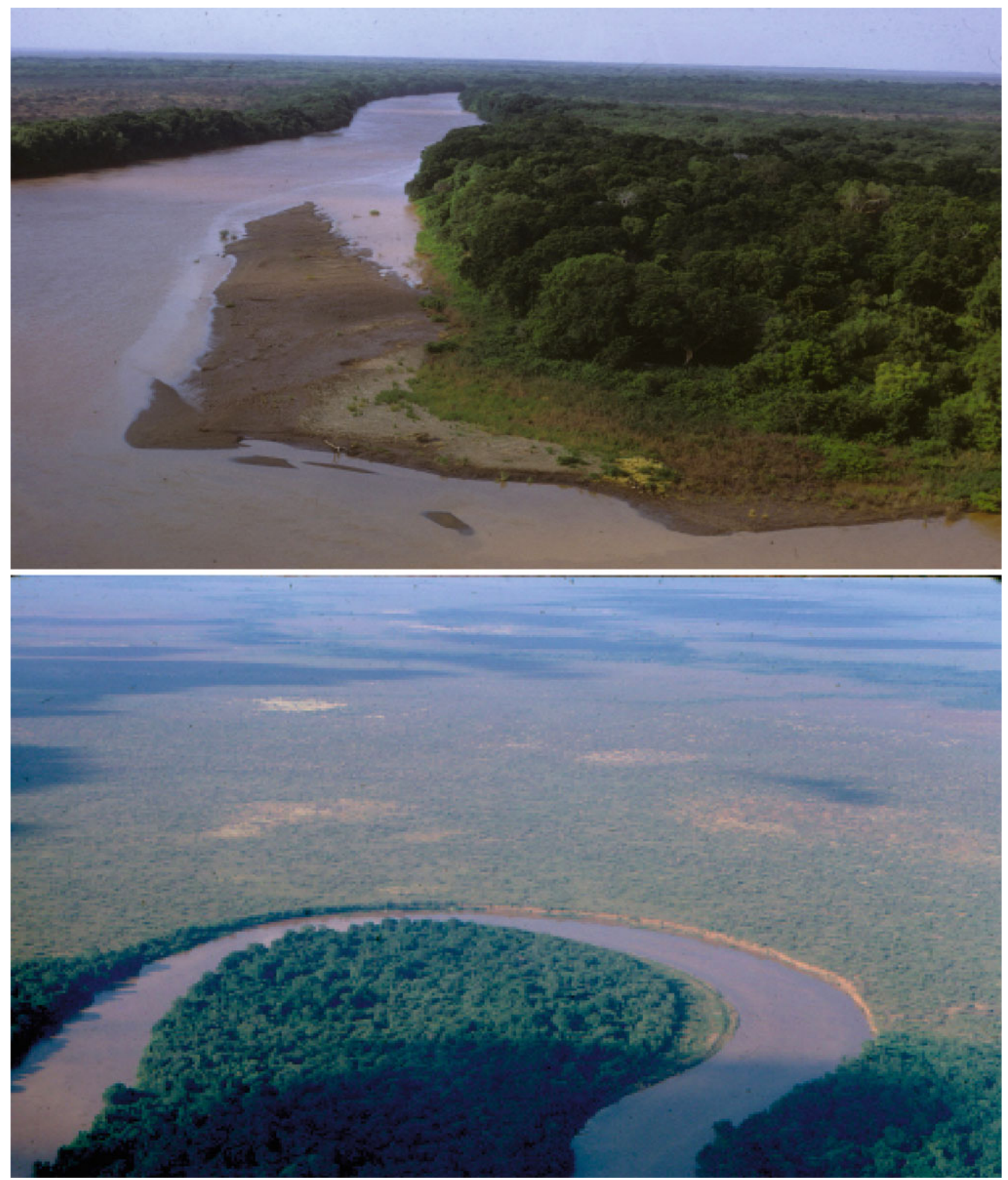

Fig. 1.12 Meandering section of the lower basin Omo River. Top Sand spit with indigenous flood recession agriculture along (annually flooded) waterside flat and forest on higher (not flooded) natural levee. Bottom Well-developed forest (trees to 27-m height) on inside bend of meander versus semi-arid vegetation along the 'outside' bend 
A major earthquake occurrence of 7 or 8 magnitude is predictable for the Gibe III dam portion of the Ethiopian Rift Valley within the next fifty years (see Chap. 3). According to available documents, dam collapse-whether caused directly by an earthquake or by a seismic event combined with landslides or sediment buildup behind the dam-is certainly plausible and would produce cataclysmic destruction of human life both in the lowermost Omo basin and around Kenya's Lake Turkana. In addition to unprecedented human destruction from such an event, the financial costs of a major dam disaster would add incalculable burden to the citizens of both nations. Chapter 3 details this threat to the peoples downstream in Ethiopia and Kenya.

$>$ The Ethiopian government is already implementing its plans for an extensive system of dam enabled, large-scale irrigated commercial farms along the lower Omo River accompanied by GOE evictions of tens of thousands of indigenous residents. As detailed in later chapters, hundreds of thousands of hectares are allocated by the GOE for these state owned and private enterprises which are being constructed on the traditional lands of multiple ethnic groups. Massive land areas and resources essential to the livelihoods of these groups are being expropriated, with accompanying eviction of tens of thousands of villagers.

- Major abstraction of river waters for these irrigated large-scale commercial farms along the Omo would both multiply and indefinitely extend the radical reduction of Omo flow volume and lake inflow during the Gibe III reservoir-filling period. In combination, these two major sources of water denial to the downstream system and the elimination of the river's annual flood which is vital for sustainment of downstream survival systems would create catastrophic losses for hundreds of thousands of pastoral, agropastoral and fishing residents.

Large-scale irrigated farm enterprises along the Omo are dependent on the Gibe III dam's regulation of the river-a fact ignored or directly misrepresented in government and development bank assessments of 2009 and 2010 (see Chap. 6). The fixed irrigation systems and high-value crops of these large-scale farms necessitate a predictable and calibrated abstraction of river water in order to maximize agricultural productivity. ${ }^{13}$

- Widespread Ethiopian government expropriation of indigenous villagers for the establishment of irrigated commercial private and government plantations has been underway for at least five years in both the higher altitude Mursi portion and the Dasanech/Nyangatom portion of the lower Omo basin. This process is documented by international human rights organizations for the traditional lands of the Mursi and their neighbors (Fig. 1.3). To the extent possible, SONT researchers have documented the expropriation process in the less accessible Dasanech (and Nyangatom) lands in the lowermost Omo basin (see Chaps. 7 and 8).

Most of the Dasanech communities that have been expropriated from their traditional lands along the lowermost Omo have no option but to take refuge within (or nearby) the modern Omo delta. This involuntary movement into the delta region greatly worsens the already crowded conditions there for agropastoralists and fishing communities already settled there. ${ }^{14}$

- The Ethiopian government forces respond with repressive measures—often, with brutality—when Dasanech or Nyangatom communities resist expropriation from their riverine lands. Fear among villagers throughout the region is intensifying. Such political repression and the GOE's denial of residents' access to river waters essential to their survival constitute human rights violations, as defined by the United Nations and other international bodies. A culture of fear pervades villages throughout the region where communities are already desperately searching for a means of survival.

The response of the Kenyan government (GOK) to the survival plight of indigenous pastoralists and fishers around Lake Turkana indicates a predominant attitude of indifference. This view is reflected in World Bank statements in internal documents, for example, citing the high likelihood of the GOK "overlooking" impacts of lake retreat on its indigenous population in favor of Gibe III dam electricity generated that is contracted for export to that 'power deficit' nation.

\footnotetext{
${ }^{13}$ A large sugar plantation already under development (the Kuraz plantation) in traditional Mursi lands (Fig. 1.3) has a regulated water sourcethrough a weir already constructed in that locality.

${ }^{14}$ Some households with remaining livestock relocate to degraded grazing lands around the northeastern shoreline of Lake Turkana-risking major hostilities with Turkana pastoralists.
} 
Resistance among Turkana communities to the Gibe III dam — and other developments in the region-met with increasing militarization by the GOK. Community leaders report government warnings to activists and threats of reprisal for protest of GOK policies.

The matter of violation of U.N. defined human rights - especially the human right to adequate water with its accompanying rights to livelihood, health and freedom from political repression-is outlined in Chap. 10.

\section{Literature Cited}

Brown, F.H., B. Haileab, and I. McDougall. 2006. Sequence of Tuffs between the KBS Tuff and the Chari Tuff in the Turkana Basin, Kenya and Ethiopia. Geological Society of London 163(1): 185-204.

Bruhn, R.L., F.H. Brown, P.N. Gathogo, and B. Haileab. 2011. Pliocene volcano-tectonics and paleogeography of the Turkana Basin, Kenya and Ethiopia. Journal of African Earth Sciences 59(2-3): 295-312.

Butzer, K.W. 1970. Contemporary depositional environments of the Omo delta. Nature 226: 15.

Butzer, K.W. 1971. Recent history of an Ethiopian Delta. University of Chicago Department of Geography Papers No. 136.

Cerling, T.E. 1986. A mass-balance approach to basin sedimentation: constraints on the recent history of the Turkana basin. Palaeogeography, Palaeoclimatology, Palaeoecology 54: 63-86.

Ethiopia, Government of, Ethiopian Electric Power Corporation (EEPCO). 2009a. CESI, Mid-Day International Consulting Engineers (MDI), Gibe III Hydroelectric Project, Environmental and Social Impact Assessment, Report No. 300 ENV RC 002C Plan.

Ethiopia, Government of, Ethiopian Electric Power Corporation (EEPCO). 2009b. Agriconsulting S.P.A., Mid-Day International Consulting, Level 1 Design, Environmental and Social Impact Assessment, Additional Study of Downstream Impacts. Report No. 300 ENV RAG 003B.

Ethiopia, Government of, Ethiopian Electric Power Corporation (EEPCO) n.d., A. Samuel, The first hydro power station in Ethiopia. www.eepco. gov.et/corporationhistory.php.

European Investment Bank (EIB). (2010, Mar). Sogreah Consultants, Independent Review and Studies Regarding the Environmental \& Social Impact Assessments for the Gibe III Hydropower Project, Final Report, 183 pp.

Hathaway, T. 2008. What cost Ethiopia's dam boom? A look inside the expansion of Ethiopia's energy sector. International Rivers. http://www. internationalrivers.org.

Hinshaw, R.E. 2006. Living with Nature's Extremes: The Life of Gilbert Fowler White. Johnson Books, 338 pages.

Kenya, Government of 2011/2012, Annual Report and Financial Statements.

Ketraco (Kenya Electricity Transmission Co. Ltd.). 2006. Eastern Africa Interconnector (Ethiopia—Kenya). http://www.ketraco.co.ke/projects/ ongoing/ethiopia-suswa-k.html.

Leslie, J. 2005. Deep Water. The Epic Struggle Over Dams, Displaced People and the Environment. Farrar, Straus and Gireau, New York.

McCully, P. 2001. Silenced Rivers. The Ecology and Politics of Large Dams. New York: Zed Press.

Mitchell, A. 2009. Gilgel Gibe III dam Ethiopia: technical, engineering and economic feasibility study report. Presentation transcript, submitted to African Development Bank. Personal communication, manuscript.

St. Petersburg Times. (1945, Sept. 7), Ethiopian Emperor Grants Sinclair Oil Concessions.

United States, Government of NASA Johnson Space Center Collection. 2009. Earth observation of Omo River Delta, Lake Turkana. http://www. nasaimages.org.

World Commission on Dams (WCD). 2000. Dams and Development. London: Earthscan. 198 pages.

Open Access This chapter is distributed under the terms of the Creative Commons Attribution-NonCommercial 2.5 International License (http:// creativecommons.org/licenses/by-nc/2.5/), which permits any noncommercial use, duplication, adaptation, distribution and reproduction in any medium or format, as long as you give appropriate credit to the original author(s) and the source, provide a link to the Creative Commons license and indicate if changes were made.

The images or other third party material in this chapter are included in the work's Creative Commons license, unless indicated otherwise in the credit line; if such material is not included in the work's Creative Commons license and the respective action is not permitted by statutory regulation, users will need to obtain permission from the license holder to duplicate, adapt or reproduce the material. 